DOI: $10.31393 /$ reports-vnmedical-2021-25(3)-04

UDC: $616.314 .26-053.7-073.75$

\title{
REGRESSION MODELS OF TELERADIOGRAPHIC PARAMETERS ACCORDING TO THE BJORK METHOD IN YOUNG MEN AND YOUNG WOMEN WITH ORTHOGNATHIC OCCLUSION
}

\author{
Vakhovskyi V. V. \\ National Pirogov Memorial Medical University, Vinnytsya (Pyrogov street, 56, Vinnytsya, Ukraine, 21018)
}

Responsible for correspondence: e-mail: vitalyvahovsky@gmail.com

Received: June, 30, 2021; Accepted: August, 02, 2021

\begin{abstract}
Annotation. The ability to predict the values of certain teleradiographic indicators and their correlations for young people in need of dental care is a promising area of research. The data obtained will be able to more accurately help doctors build a treatment plan. The aim of the study was to build and analyze regression models of teleradiographic parameters according to the Bjork method in young men and young women with orthognathic occlusion. Cephalometric analysis of lateral teleradiograms (49 young men and 76 young women with orthognathic occlusion) according to the modification of the Bjork A. - CFT-Bjork method, performed using OnyxCeph ${ }^{3}{ }^{T M}$ software, 3DPro version, from Image Instruments $\mathrm{GmbH}$, Germany. Cephalometric parameters were divided into three groups: the first - metric characteristics of the skull, which are used as baseline indicators; the second - indicators of the upper and lower jaws; third - indicators that characterize the position of the teeth relative to each other, cranial structures and the profile of the soft tissues of the face. Regression models of teleradiographic indicators by the Bjork method are built in the license package "Statistica 6.0". When modeling teleradiography indicators according to the Bjork method, which were included in the second group, depending on the indicators of the first group in young men with orthognathic occlusion, 9 out of 13 possible reliable regression models with a coefficient of determination greater than $0.5\left(R^{2}=\right.$ from 0.528 to 0.775$)$ were constructed. The constructed regression equations most often include the value of the angles S-N-Pog, NSL/NL, NSL/ML, NL/ML, A-N-Pog, S-N-B and the distance li-ls. In young women with orthognathic occlusion, 7 reliable models of indicators of the third group were constructed depending on the indicators of the first and second groups $(R 2=$ from 0.508 to 0.844$)$. The constructed regression equations most often include the value of the angles NSL/ML, $N L / M L, A-N-P o g, M L / R L$ and $A-N-B$. In young men and young women, the models of indicators belonging to the second group, depending on the indicators of the first group, had coefficients of determination less than 0.5 , or were not built at all.
\end{abstract}

Keywords: regression analysis, teleradiography, Bjork cephalometry, Ukrainian young men and young women with orthognathic occlusion.

\section{Introduction}

Young people and adolescents most of all need to perform orthodontic manipulations to correct malocclusion, dentition, crowding of teeth and more. That is why modern medicine is interested in the development of the theoretical basis of orthodontics - odontology, a branch of anthropology that studies the structure and evolution of the dental system and is closely intertwined with issues of study of its norm and pathology.

Cephalometric analysis allows the most effective and accurate to plan and predict the outcome of treatment by a practicing orthodontist. In particular, it simplifies the measurement of the introduction of new technologies such as neural networks, which allow to achieve good results in $97.39 \%$ of cases [3].

One of the important areas of research in modern odontology is the assessment of normative indicators of teleradiographic indicators and their relationships with each other in different types of occlusion, especially in orthognathic [19].

Domestic researchers are actively conducting research to study the relationships of different structures of the dental system for the needs of different branches of science both dentistry and anthropology, and for forensic dentistry $[8,14]$.
Regression models for modeling the position of central incisors in Ukrainian boys and girls according to Steiner's cephalometric analysis were constructed [8]. The peculiarities of correlations of linear sizes of molars with cephalometric indicators for men of the first mature age living in the western [10] and southern regions of Ukraine [18] are also studied.

Regression models for linear dimensions necessary for the construction of the correct shape of dental arches in men, residents of Ukraine, who have a wide type of face, depending on the characteristics of cephalometric and odontometric parameters [14] are build.

Thus, we can already see the achievements of domestic science to improve the fundamental theoretical basis of odontology. The wide range of work proves the validity and necessity of further research to assess the relationship between different indicators of the dental system, in particular, with different methods of cephalometric analysis and sampling of young people, taking into account at least their nationality and sex.

The aim of the study was to build and analyze regression models of teleradiographic parameters according to the Bjork method in young men and young women with orthognathic occlusion. 


\section{Materials and methods}

Teleradiography in the mode of cephalometric examination was performed using a dental cone-beam tomograph Veraviewepocs 3D Morita (Japan) 49 young men (aged 17 to 21 years) and 76 young women (aged 16 to 20 years) who had a physiological bite as close as possible to orthognathic (further orthognathic) which is defined on 11 points by M. G. Bushan, et al. [5]. Cephalometric analysis modified by A. Bjork [4] - CFT-Bjork, performed using OnyxCeph ${ }^{3 \text { TM }}$ software, 3DPro version, Image Instruments $\mathrm{GmbH}$, Germany (software license № URSQ-1799).

Cephalometric points were determined in accordance with the recommendations of B. S. Phulari [16] and S. I. Doroshenko and E. A. Kulginsky [9].

Cephalometric parameters according to the Bjork method were divided into three groups according to $\mathrm{M}$. O. Dmitriev [7]. The first group includes metric characteristics of the skull, which are used as basic indicators in the methods of cephalometric analysis; to the second group dental-jaw in which the skeleton has already been formed and which surgical methods can change the length, width, angles and positions of the upper and lower jaws; to the third group - indicators that actually characterize the position of each individual tooth relative to each other, cranial structures and the profile of the soft tissues of the face.

Cephalometric measurements according to the Bjork method included the determination of the following parameters [21, 22]:

the first group - the angle N-S-Ar, characterizes the position of the temporomandibular joint $\left({ }^{\circ}\right)$; angle $\mathbf{N}-\mathbf{S}-\mathbf{B a}$, characterizes the angle of the skull base $\left({ }^{\circ}\right)$; the ratio $\mathrm{N}$ S:S-Ar', characterizes the position of the projection of the temporomandibular joint on the line $\mathbf{N}-\mathbf{S}$ (conventional units);

the second group - the angle A-N-B, characterizes the position of the jaws to each other $\left({ }^{\circ}\right)$; angle A-N-Pog, characterizes the inter-jaw position in the sagittal plane $\left(^{\circ}\right)$; angle S-N-A, characterizes the position of the upper jaw in the sagittal plane $\left({ }^{\circ}\right)$; angle $\mathbf{S}-\mathbf{N}-\mathbf{B}$, characterizes the position of the lower jaw in the sagittal plane $\left(^{\circ}\right)$; NSL/NL angle, characterizing the inclination of the upper jaw to the anterior base of the skull $\left({ }^{\circ}\right)$; NSL/ML angle, characterizes the inclination of the body of the lower jaw to the anterior base of the skull $\left({ }^{\circ}\right)$; angle $\mathbf{M L} / \mathbf{R L}$, characterizes the angle of the lower jaw $\left({ }^{\circ}\right)$; angle $\mathbf{N L} / \mathbf{M L}$, characterizes the position of the closing plane to the palatal plane $\left(^{\circ}\right)$; angle S-N-Pog, characterizes the position of the lower jaw in the sagittal plane $\left({ }^{\circ}\right)$; distance li-Is, characterizes the inter-incisal overlap in the vertical plane $(\mathrm{mm})$;

the third group - the angle Pr-N-A, characterizes the position of the maxillary alveolar process $\left({ }^{\circ}\right)$; angle $\mathbf{C L} / \mathbf{M L}$, characterizes the position of the mandibular alveolar process $\left({ }^{\circ}\right)$; the angle ILs/NL, characterizes the position of the upper medial incisor to the palatal plane $\left(^{\circ}\right)$; angle ILi/ $\mathbf{M L}$, characterizes the position of the lower medial incisor to the plane of the mandible $\left({ }^{\circ}\right)$; angle $\mathbf{O L s} / \mathbf{N L}$, characterizes the position of the closing plane to the palatal plane $\left(^{\circ}\right)$; angle $\mathbf{O L i} / \mathbf{M L}$, characterizes the position of the closing plane to the mandibular plane $\left({ }^{\circ}\right)$; angle $\mathbf{O L f} / \mathbf{N S L}$, characterizes the position of the closing plane to the base of the skull $\left({ }^{\circ}\right)$; the angle ILs/ILi, characterizes the inclination of the upper and lower medial incisors to each other $\left({ }^{\circ}\right)$; distance Is-NCL, characterizes the position of the upper lip $(\mathrm{mm})$; distance li-NCL, characterizes the position of the lower lip $(\mathrm{mm})$; Wits distance, characterizes the linear ratio of the lower and upper jaws along the flexing plane $(\mathrm{mm})$; Is-Olf distance, characterizes the vertical location of the cutting edge of the medial incisor $(\mathrm{mm})$; Overjet distance, characterizes the inter-incisor distance in the sagittal plane ( $\mathrm{mm}$ )

Regression models of teleradiographic indicators by the Bjork method are built in the license package "Statistica 6.0".

\section{Results. Discussion}

In young men with orthognathic occlusion, the coefficients of determination of the regression equations of the values of the angles S-N-A, S-N-Pog, S-N-B, A-NPog, A-N-B, NSL/ML and NL/ML by the Bjork method (belong to the second group) depending on the teleradiographic characteristics of the basal cranial structures (belong to the first group) were from 0.05 to 0.17 and therefore the constructed models had no practical significance; and the regression equations of the distance li-ls and the values of the angles NSL/NL and ML/RL were not constructed at all.

In young men with orthognathic occlusion, reliable models of teleradiographic indicators by the Bjork method with a coefficient of determination greater than 0.5 , which were included in the third group depending on the indicators of the first and second groups have the form of the following linear equations:

CL/ML (young men) $=143.2+4.167 \times \mathrm{A}-\mathrm{N}-\mathrm{Pog}-0.707$ x NSL/ML - $2.705 \times$ x-N-B - $0.594 \times$ S-N-A $\left(R^{2}=0.758\right.$; $F_{(4.44)}=34.55 ; p<0.0000$; Error of estimate $\left.=2.728\right)$;

ILs/NL (young men) $=-54.76+1.594 \times \mathrm{S}-\mathrm{N}-\mathrm{B}+0.548 \times$ $\mathrm{NSL} / \mathrm{NL}+0.258 \times \mathrm{N}-\mathrm{S}-\mathrm{Ba}\left(\mathrm{R}^{2}=0.627 ; \mathrm{F}_{(3.45)}=25.22\right.$; $\mathrm{p}<0.0000$; Error of estimate $=3.478$ );

ILi/ML (young men) $=109.0-0.273 \times \mathrm{ML} / \mathrm{RL}+1.823 \times \mathrm{A}-$ $\mathrm{N}-\mathrm{Pog}-0.583 \times \mathrm{NSL} / \mathrm{ML}+0.292 \times \mathrm{N}-\mathrm{S}-\mathrm{Ba}-0.479 \times \mathrm{NSL} / \mathrm{NL}$ $\left(R^{2}=0.775 ; F_{(5.43)}=29.63 ; p<0.0000\right.$; Error of estimate=3.685);

Overjet (young men) $=-10.71+0.207 \times \mathrm{S}-\mathrm{N}-\mathrm{A}+0.056 \mathrm{x}$ N-S-Ba $+0.268 \times$ li-ls $-0.157 \times$ NSL/NL $-0.133 \times$ S-N-Pog $\left(R^{2}=0.673 ; F_{(5.43)}=17.72 ; p<0.0000\right.$; Error of estimate=0.590);

Wits $($ young men) $=20.36+1.908 \times \mathrm{A}-\mathrm{N}-\mathrm{B}-0.834 \times \mathrm{A}-\mathrm{N}-$ Pog - $0.212 \times \mathrm{NSL} / \mathrm{ML}-0.234 \times \mathrm{S}-\mathrm{N}-\mathrm{B}\left(\mathrm{R}^{2}=0.630\right.$; $F_{(4.44)}=18.75 ; p<0.0000$; Error of estimate $\left.=1.797\right)$;

OLs/NL (young men) $=67.99-0.756 \times$ S-N-Pog -0.527 $\times \mathrm{NSL} / \mathrm{NL}+0.763 \times$ li-ls $+0.187 \times \mathrm{NL} / \mathrm{ML}\left(\mathrm{R}^{2}=0.648\right.$; $\mathrm{F}_{(4.44)}=20.28 ; \mathrm{p}<0.0000$; Error of estimate $\left.=2.386\right)$;

OLi/ML (young men) $=-69.43+0.845 \times \mathrm{NL} / \mathrm{ML}+1.492$ $x$ S-N-Pog $+0.533 \times \mathrm{NSL} / \mathrm{NL}+0.687 \times$ li-ls $-0.739 \times \mathrm{S}-\mathrm{N}-\mathrm{B}$ $\left(R^{2}=0.606 ; F_{(5.43)}=13.24 ; p<0.0000 ;\right.$ Error of estimate=2.619); 
OLf/NSL (young men) $=55.39+0.512 \times N S L / M L-0.462$ x S-N-Pog - $0.148 \times \mathrm{ML} / \mathrm{RL}\left(\mathrm{R}^{2}=0.722 ; \mathrm{F}_{(3.45)}=38.96\right.$; $\mathrm{p}<0.0000$; Error of estimate $=2.769)$;

Is-OLf (young men) $=12.61+0.511 \times$ li-ls $-0.104 \times \mathrm{NL} /$ $\mathrm{ML}$ - 0.134 x S-N-Pog $\left(R^{2}=0.528 ; F_{(3.45)}=16.79 ; p<0.0000\right.$; Error of estimate $=0.799)$;

where, $R^{2}$ is the coefficient of determination; $F_{(!, ! !)}=! !$critical (!!) and obtained (!!) value of Fisher's criterion; $p$ the level of reliability of the model; Std. Error of estimate standard estimation error.

Thus, when modeling teleradiographic indicators according to the Bjork method, included in the second group, depending on the indicators of the first group in young men with orthognathic occlusion, 9 out of 13 possible reliable regression models with a coefficient of determination greater than $0.5\left(R^{2}=\right.$ from 0.528 to 0.775$)$ are build. The constructed regression equations most often include the value of the angles S-N-Pog, NSL/NL (13.89\% each), the angle NSL/ML and the distance li-ls $(11.11 \%$ each) and the angles NL/ML, A-N-Pog and S-N-B (8.33\% each). In young men, the coefficients of determination of the regression equations of the angles $\mathrm{Pr}-\mathrm{N}-\mathrm{A}$ and ILs/lli and the distances Is-NCL and li-NCL by the Bjork method depending on the teleradiographic characteristics of the basal cranial structures and upper and lower jaws were from 0.26 to 0.43 and therefore, the constructed models had no practical significance.

In young women with orthognathic occlusion, the coefficients of determination of the regression equations of the magnitude of the angles S-N-A, S-N-Pog, S-N-B, NSL/NL, NSL/ML and ML/RL by the Bjork method (belong to the second group) depending on the teleradiographic characteristics of the basal cranial structures (belong to the first group) were equal to 0.03 to 0.29 and therefore the constructed models had no practical significance; and the regression equations of the distance li-ls and the values of the angles A-N-Pog, A-N$B$ and NL/ML were not constructed at all.

In young women with orthognathic occlusion, reliable models of teleradiographic indicators by the Bjork method with a coefficient of determination greater than 0.5 , which were included in the third group depending on the indicators of the first and second groups have the form of the following linear equations:

$\boldsymbol{P r}-\mathrm{N}-\boldsymbol{A}$ (young women) $=6.542-0.844 \times \mathrm{A}-\mathrm{N}-\mathrm{B}+0.478$ $x \mathrm{~A}-\mathrm{N}-\mathrm{Pog}+0.060 \times \mathrm{NL} / \mathrm{ML}-0.032 \times \mathrm{N}-\mathrm{S}-\mathrm{Ar}\left(\mathrm{R}^{2}=0.565\right.$; $F_{(4.71)}=23.08 ; p<0.0000$; Error of estimate $\left.=0.760\right)$;

CL/ML (young women) $=195.1+5.400 \times \mathrm{A}-\mathrm{N}-\mathrm{Pog}-$ $4.866 \times A-N-B-1.007 \times N S L / M L-1.090 \times S-N-P o g\left(R^{2}=0.844\right.$; $F_{(4.71)}=95.81 ; p<0.0000$; Error of estimate $\left.=2.430\right)$;

ILs/NL (young women) $=16.21+3.906 \times \mathrm{S}-\mathrm{N}-\mathrm{B}+1.021$ x NSL/NL - 1.171 x S-N-A - 1.591 x S-N-Pog $\left(R^{2}=0.508\right.$; $F_{(4.71)}=18.36 ; p<0.0000$; Error of estimate $\left.=4.203\right)$;

Wits $($ young women) $=22.07+1.908 \times \mathrm{A}-\mathrm{N}-\mathrm{B}-0.592 \times$ A-N-Pog - $0.266 \times$ S-N-A - $0.169 \times \mathrm{NSL} / \mathrm{ML}\left(\mathrm{R}^{2}=0.643\right.$; $F_{(4.71)}=31.95 ; p<0.0000$; Error of estimate $\left.=1.731\right)$;

OLs/NL (young women) $=25.64+0.761 \times \mathrm{NL} / \mathrm{ML}-0.293$ $x \mathrm{ML} / \mathrm{RL}+1.082 \times$ li-Is $\left(\mathrm{R}^{2}=0.541 ; \mathrm{F}_{(3.72)}=28.28 ; \mathrm{p}<0.0000\right.$; Error of estimate $=2.638)$;

OLi/ML (young women) $=-27.80+0.312 \times \mathrm{ML} / \mathrm{RL}+$ $0.228 \times \mathrm{NL} / \mathrm{ML}+0.582 \times$ li-Is $\left(\mathrm{R}^{2}=0.526 ; \mathrm{F}_{(3.72)}=26.63\right.$; $\mathrm{p}<0.0000$; Error of estimate $=2.839$ );

OLf $/$ NSL (young women) $=11.98+0.720 \times \mathrm{NSL} / \mathrm{ML}-$ $0.273 \times \mathrm{ML} / \mathrm{RL}+0.123 \times \mathrm{N}-\mathrm{S}-\operatorname{Ar}\left(\mathrm{R}^{2}=0.626 ; \mathrm{F}_{(3.72)}=40.22\right.$; $\mathrm{p}<0.0000$; Error of estimate $=2.713$ ).

Thus, when modeling teleradiographic indicators according to the Bjork method, included in the second group, depending on the indicators of the first group in young women with orthognathic occlusion, 7 out of 13 possible reliable regression models with a coefficient of determination greater than $0.5\left(R^{2}=\right.$ from 0.508 to 0.844$)$ are build. The constructed regression equations most often include the value of the angles NSL/ML, NL/ML, A-N-Pog, ML/RL and A-N-B (14.29 $\%$ each). In young women, the coefficients of determination of regression equations of the angles $\mathrm{ILi} / \mathrm{ML}$ and $\mathrm{ILS} / \mathrm{Li}$ and distances Overjet, Is-OLf, Is-NCL and li-NCL according to the Bjork method depending on the teleradiographic characteristics of the basal cranial structures and upper and lower jaws were equal to 0.23 to 0.50 and therefore the constructed models had no practical significance.

Modern research in the field of soft tissue and skeletal structures used in cephalometry is multifaceted and is devoted to the study of various aspects of the study of teleradiographic parameters [20, 23]. R. Adaskevicius and A. Vasiliauskas [1] have been proposed for use in order to obtain cephalometric parameters of a new method of structured light 3D scanning.

H. T. Mahmood and M. Fida [13] study accuracy of using the atlas for angular mandibular parameters. The authors found statistically significant, but weak correlations between different parameters of the atlas and mandible in men and women. Thus, researchers do not recommend using the atlas to predict orthodontic treatment of the mandible.

The researchers surveyed 50 Bangladeshis (25 men and 25 women) to identify normative cephalometric parameters in people with class II occlusion. The statistical analysis of the data showed significant variations in the data of individuals who differed from the data obtained by the authors in previous studies in the analysis of data of persons with bite pathology class I. Manifestations of sexual dimorphism - men had higher values than women [2].

For Germans with orthognathic occlusion, aged 6-17 years, age and sex characteristics of cephalometric indicators were established, namely: at the age of 6 years, young men have higher indicators of anterior and posterior cranial base length, mandible length and middle face length. Also, higher rates were found in young men for most craniofacial measurements in the age groups of 15-17 years. At the same time, no sex differences in angular parameters were detected [6].

A. R. Han at al. [11] have established relationships between maxillary molar size and craniofacial parameters in individuals with orthognathic occlusion. A statistically 
significant relationship was found between ConV and U6$\mathrm{SN}$. The highest value of R2 among the three constructed regression models obtained by the authors of the study was 0.880 .

The relationship of the occlusal plane with soft tissue structures in individuals with class I, II and III occlusion has been studied. Data from 60 cephalograms were used in the study. The statistical analysis of ANOVA showed a significant difference for each study class. Thus, in $75 \%$ of persons of class I and $60 \%$ of persons of class II the posterior reference point of the occlusal plane was the middle part of the tragus. In persons of III class in $75 \%$ of cases this reference point was the lower limit of the trestle [12].

At removal of the first four premolars at patients' retraction, extrusion of incisors and increase in their vertical sizes is noted that in turn influences position of lips. Statistically significant changes were observed in the values of U1-SN, IMPA, U1-PP and the sum of Bjork ( $p<0.05)$ [15].

Agenesis of the third molar leads to significant changes only in the general and upper gonial angles $(p \leq 0.05)$ [17].

These results prove the importance of studying the features of teleradiographic parameters in both normal and occlusal pathology and thus improve the understanding of the processes of orthodontic treatment and implement it in practice by Ukrainian doctors.

\section{References}

[1] Adaskevicius, R., \& Vasiliauskas, A. (2012). Three-dimensional determination of dental occlusion and facial structures using soft tissue cephalometric analysis. Elektronika ir Elektrotechnika, 121(5), 93-96. doi: 10.5755/ j01.eee.121.5.1658

[2] Alam, M. K., Nowrin, S. A., Shahid, F., Haque, S., \& Basri, R. (2014). Cephalometric Characteristics of Bangladeshi adults with Class II Malocclusion. Int Res J Med Sci, 2(11), 10-14.

[3] Anbazhagan, S. (2021). Artificial Neural Networks to Detect Facial Abnormalities through Cephalometric Radiography using Bjork Analysis. ICTACT Journal on Soft Computing, 11(4), 2391-2401. doi: 10.21917/ijsc.2021.0341

[4] Björk, A. (1966). Sutural growth of the upper face studied by the implant method. Acta Odontologica Scandinavica, 24(2), 109-127. doi: 10.3109/00016356609026122

[5] Bushan, M. H., Vasylenko, Z. S., \& Hryhoreva, L. P. (1990). Справочник по ортодонти [Handbook of orthodontics]. Кишенев: Картя Молдовеняскэ - Kishinev: Kartia Moldoveniaske.

[6] De Castrillon, F. S., Baccetti, T., Franchi, L., Grabowski, R., Klink-Heckmann, U., \& McNamara, J. A. (2013). Lateral cephalometric standards of Germans with normal occlusion from 6 to 17 years of age. Journal of Orofacial Orthopedics/ Fortschritte der Kieferorthopadie, 74(3), 236-256. doi: $10.1007 / \mathrm{s} 00056-013-0140-5$

[7] Dmitriev, М. О. (2017). Зв'язки основних краніальних показників з характеристиками положення зубів верхньої і нижньої щелеп та профілем м'яких тканин обличчя в юнаків і дівчат [Relations of key cranial indicators with the characteristics of the teeth of the upper and lower jaws and profile face soft tissue in boys and girls]. Вісник морфологіi - Reports of Morphology, 23(1), 125-131.

[8] Dmitriev, M., Gunas, V., Polishchuk, S., Olkhova, I., \& Kumar, A. (2020). Modeling of Central Incisors Position Indicators in boys

\section{Conclusions and prospects for further development}

1. In the simulation of teleradiographic indicators included in the third group according to the method of Bjork, depending on the indicators of the first and second groups in young men built 9 of 13 possible reliable regression models with a coefficient of determination greater than 0.5 $(\mathrm{R} 2=$ from 0.528 to 0.775$)$, and in young women -7 models $(\mathrm{R} 2=$ from 0.508 to 0.844$)$. In both young men and young women, the models of regression equations of indicators belonging to the second group, depending on the indicators of the first group, had coefficients of determination less than 0.5 , or were not built at all.

2. When modeling the indicators of the third group, depending on the indicators of the first and second groups in young men, the constructed equations most often include the value of the angles S-N-Pog, NSL/NL (13.89\% each), the angle NSL/ML and the distance li-ls (11.11\% each) and angles NL/ML, A-N-Pog and S-N-B (8.33\% each), and young women - the value of the angles NSL/ML, NL/ML, A$\mathrm{N}-\mathrm{Pog}, \mathrm{ML} / \mathrm{RL}$ and A-N-B (14.29\% each).

Further research is planned to develop a computer program that will allow orthodontists to quickly analyze teleradiograms using the Bjork method and compare the results with the data obtained by us in Ukrainian young men and young women with orthognathic occlusion.

and girls according to CC. Steiner method for Forensic Dental Identification. The Official Publication of Indian Academy of Forensic Medicine, 42(3), 155-160. doi: 10.5958/09740848.2020.00043.3

[9] Doroshenko, S. I., \& Kulginsky, Е. А. (2007). Основы телерентгенографрии [Fundamentals of teleradiography]. К.: Здоров'я - K.: Zdorovija.

[10] Gunas, V. I., Kotsyura, O. O., Babych, L. V., Shevchuk, Y. G., \& Cherkasova, O. V. (2020). Features correlations of the sizes of molars with cephalometric indicators of men of the western region of Ukraine. Reports of Morphology, 26(2), 51-61. doi: 10.31393/morphology-journal-2020-26(2)-08

[11] Han, A. R., Kim, J., \& Yang, I. H. (2021). Relationship between vertical components of maxillary molar and craniofacial frame in normal occlusion: Cephalometric calibration on the vertical axis of coordinates. Korean Journal of Orthodontics, 51(1), 15-22. doi: 10.4041/kjod.2021.51.1.15

[12] Lahori, M., Nagrath, R., \& Malik, N. (2013). A cephalometric study on the relationship between the occlusal plane, AlaTragus and Camper's lines in subjects with Angle's class I, class II and class III occlusion. The Journal of Indian Prosthodontic Society, 13(4), 494-498. doi: 10.1007/s13191012-0215-9

[13] Mahmood, H. T., \& Fida, M. (2018). Correlation between the atlas morphology and the maxillo-mandibular divergence pattern. Journal of the College of Physicians and Surgeons, 28(9), 690-694. doi: 10.29271/jcpsp.2018.09.690

[14] Marchenko, A. V., Shinkaruk-Dykovytska, M. M., Pozur, T. P., Gunas, V. I., \& Orlovskiy, V. O. (2020). Models of individual linear dimensions necessary for the construction of the correct form of dental arches in young men with a wide face, depending on the features of odontometric and cephalometric indicators. Wiadomosci lekarskie (Warsaw, Poland: 1960), 73(6), 11031107. PMID: 32723934 
[15] Mortazavi, M., Chalipa, J., Mogadam, N. E., Hakim, L. K., \& Davani, S. T. (2019). Face Vertical Dimension Change and Incisors Position Following Orthodontic Treatment with Extraction of Four First Premolars. Journal of Regeneration, Reconstruction \& Restoration (Triple R), 4(3), 117-120. doi: 10.22037/rrr.v4i3.29580

[16] Phulari, B. (2013). An atlas on cephalometric landmarks. JP Medical Ltd. doi: 10.5005/jp/books/11877

[17] Ramiro-Verdugo, J., De Vicente-Corominas, E., MontielCompany, J. M., Gandia-Franco, J. L., \& Bellot-Arcis, C. (2015). Association between third molar agenesis and craniofacial structure development. American Journal of Orthodontics and Dentofacial Orthopedics, 148(5), 799-804. doi: 10.1016/ j.ajodo.2015.05.025

[18] Soboń, J. S., Cherkasova, O. V., Gunas, V. I., Babych, L. V., \& Kotsyura, O. O. (2020). Correlations of linear sizes of molars with cephalometric indicators of practically healthy men of the southern region of Ukraine. Biomedical and Biosocial Anthropology, 38, 36-46. doi: 10.31393/bba38-2020-06

[19] Strajnić, L., \& Stanišić-Sinobad, D. (2012). Application of cephalometric analysis for determination of vertical dimension of occlusion: A literature review. Medicinski pregled, 65(56), 217-222. doi: 10.2298/MPNS1206217S

[20] Tavano, K. T., Seraidarian, P. I., de Oliveira, D. D., \& Jansen, W.
C. (2012). Determination of vertical dimension of occlusion in dentate patients by cephalometric analysis-pilot study. Gerodontology, 29(2), e297-e305. doi: 10.1111/j.17412358.2011.00469.x

[21] Vakhovskyi, V. V. (2021). Correlations of teleradiographic parameters of teeth location determined by the methods of Bjork, Jarabak and Sassouni with the parameters of the upper and lower jaws in young men and young women with orthognathic occlusion. Вісник Вінницького національного медичного університету - Reports of Vinnytsia National Medical University, 25(2), 229-237. doi: 10.31393/reportsvnmedical-2021-25(2)-08

[22] Vakhovskyi, V. V., Shinkaruk-Dykovytska, M. M., Pogorila, A. V., Likhitskyi, O. O., \& Gunas, I. V. (2020). Correlations of basal cranial structures characteristics determined by Bjork and Jarabak methods with teleradiographic parameters of the upper and lower jaws and tooth location in young men and young women with orthognathic occlusion. Biomedical and Biosocial Anthropology, 41, 52-59. doi: 10.31393/bba41-202009

[23] Wabgaonkar, O. V., Sheth, V. H., Kalra, D., \& Bhate, P. (2019). Association of Impacted Third Molars with Facial Growth Patterns among Adult Indian Patients-A Retrospective Study. Int J Sci Stud, 6(10), 55-61.

\section{РЕГРЕСІЙНІ МОДЕЛІ ТЕЛЕРЕНТГЕНОГРАФІЧНИХ ПОКАЗНИКІВ ЗА МЕТОДОМ ВЈОRК В ЮНАКІВ І ДІВЧАТ ІЗ ОРТОГНАТИЧНИМ ПРИКУСОМ \\ Ваховський В. В.}

Анотація. Можливість передбачення значень тих чи інших телерентгенометричних показників та їх взаємозв'язку для осіб молодого віку, що потребують одонтологічної допомоги, $є$ перспективним напрямком наукових робіт. Отримані дані зможуть з більшою точністю допомогти лікарям побудувати план лікування. Мета дослідження - побудувати та провести аналіз регресійних моделей телерентгенографічних показників за методом Bjork в юнаків і дівчат із ортогнатичним прикусом. Цефралометричний аналіз бокових телерентгенограм (49 юнаків і 76 дівчат із ортогнатичним прикусом) за

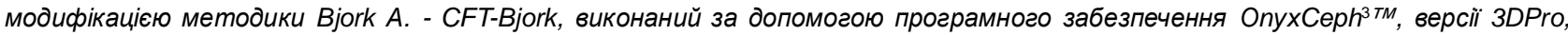
компанії Image Instruments GmbH, Німеччина. Цефалометричні параметри були розділені на три групи: перша - метричні характеристики черепа, які використовуються як базові показники; друга - показники верхньої й нижньої щелеп; третя показники, які характеризують положення зубів відносно один одного, черепних структур і профрілю м'яких тканин обличя. Регресійні моделі телерентгенографрічних показників за методом Bjork побудовані в ліцензійному пакеті "Statistica 6.0". При моделюванні телерентгенографрічних показників за методикою Bjork, що увійшли до другої групи в залежності від показників першої групи в юнаків із ортогнатичним прикусом, побудовані 9 із 13 можливих достовірних регресійних моделей з коефіцієнтом детермінації більшим 0,5 $\left(R^{2}=\right.$ від 0,528 до 0,775). До побудованих регресіних рівнянь найбільш часто входять величина кутів S-N-Pog, NSL/NL, NSL/ML, NL/ML, A-N-Pog, S-N-B і відстані li-Is. У дівчат із ортогнатичним прикусом побудовані 7 достовірних моделей показників третьої групи в залежності від показників першої та другої груп $\left(R^{2}=\right.$ від 0,508 до 0,844). До побудованих регресіних рівнянь найбільш часто входять величина кутів NSL/ML, NL/ML, A-N-Pog, ML/RL i A-N-B. В юнаків і у дівчат моделі показників, що відносяться до другої групи в залежності від показників першої групи, мали коефріцієнти детермінації менше 0,5, або взагалі не були побудовані.

Ключові слова: регресійний аналіз, телерентгенографрія, цефалометрія за методом Bjork, українські юнаки та дівчата з ортогнатичним прикусом. 